Research Article

\title{
MLL leukemia-associated rearrangements in peripheral blood lymphocytes from healthy individuals
}

\author{
María Sol Brassesco ${ }^{1,2}$, Ana Paula Montaldi ${ }^{1}$, Diana Ester Gras ${ }^{1}$, Rosane Gomes de Paula Queiroz ${ }^{2}$, \\ Nilce Maria Martinez-Rossi ${ }^{1}$, Luiz Gonzaga Tone ${ }^{2}$ and Elza Tiemi Sakamoto-Hojo ${ }^{1,3}$ \\ ${ }^{1}$ Departamento de Genética, Faculdade de Medicina de Ribeirão Preto, Universidade de São Paulo, \\ Ribeirão Preto, SP, Brazil. \\ ${ }^{2}$ Departamento de Puericultura e Pediatria, Faculdade de Medicina de Ribeirão Preto, \\ Universidade de São Paulo, Ribeirão Preto, SP, Brazil. \\ ${ }^{3}$ Departamento de Biologia, Faculdade de Filosofia, Ciências e Letras, Universidade de São Paulo, \\ Ribeirão Preto, SP, Brazil.
}

\begin{abstract}
Chromosomal translocations are characteristic of hematopoietic neoplasias and can lead to unregulated oncogene expression or the fusion of genes to yield novel functions. In recent years, different lymphoma/leukemia-associated rearrangements have been detected in healthy individuals. In this study, we used inverse PCR to screen peripheral lymphocytes from 100 healthy individuals for the presence of MLL (Mixed Lineage Leukemia) translocations. Forty-nine percent of the probands showed $M L L$ rearrangements. Sequence analysis showed that these rearrangements were specific for $M L L$ translocations that corresponded to $t(4 ; 11)(q 21 ; q 23)(66 \%)$ and $t(9 ; 11)(20 \%)$. However, RT-PCR failed to detect any expression of $t(4 ; 11)(q 21 ; q 23)$ in our population. We suggest that $11 q 23$ rearrangements in peripheral lymphocytes from normal individuals may result from exposure to endogenous or exogenous DNA-damaging agents. In practical terms, the high susceptibility of the MLL gene to chemically-induced damage suggests that monitoring the aberrations associated with this gene in peripheral lymphocytes may be a sensitive assay for assessing genomic instability in individuals exposed to genotoxic stress.
\end{abstract}

Key words: genomic instability, lymphocytes, $M L L$ rearrangements.

Received: May 30, 2008; Accepted: October 16, 2008.

\section{Introduction}

Lymphoid neoplasias are generally characterized by the presence of chromosomal anomalies, the most prominent of which are those that produce in-frame fusion genes. These aberrations are important diagnostic tools that can be used to establish the prognosis of leukemias and lymphomas and monitor their progress.

Rearrangements of the Mixed Lineage Leukemia $(M L L)$ gene generated by reciprocal translocations involving chromosome band 11q23 are well-known in infants and adults with acute myeloid leukemia (AML) and acute lymphoblastic leukemia (ALL), as well as in $85 \%$ of secondary leukemias associated with a history of treatment with topoisomerase II inhibitors (Adler et al., 1999; Ross, 2000). More than 50 fusion genes involving $M L L$ associated with a poor prognosis have been identified (Popovic

Send correspondence to María Sol Brassesco. Departamento de Puericultura e Pediatria, Faculdade de Medicina de Ribeirão Preto, Universidade de São Paulo, Av. Bandeirantes 3900, 14040-900 Ribeirão Preto, SP, Brazil. E-mail: marsol@rge.fmrp.usp.br, solbrassesco@ hotmail.com. and Zeleznick-Le, 2005; Slany, 2005). However, despite the diversity and frequency of $M L L$ translocations, most of the breakpoints have been mapped within a BamH1delimited region known as the break cluster region or BCR (Sai-Peng and Liu, 2001) between exons 8 and 14 (Nilson et al., 1996; Schnittger, 1998; Echlin-Bell et al., 2003). Other aberrations involving $M L L$ in leukemia include in tandem duplications represented by in-frame repetitions of exons 2-6 (or 2-8) that can be attributed to homologous recombination mediated by Alu repeats (Strout et al., 1998; Whitman et al., 2001).

Since the development of leukemia and solid tumors is a multistage process that requires multiple cooperative mutations, it seems plausible that different mutations, such as typically found in patients with leukemia or lymphoma, could arise in normal individuals (Hunger and Cleary, 1998).

The presence of tumor-associated fusion genes in healthy donors has been described for the translocation $\mathrm{t}(14 ; 18)$ IGH/BCL2 (characteristic of non-Hodgkin lymphomas), with variable frequencies (16.2\%-55\%) among 
populations and a tendency to increase with age (Liu et al., 1994; Summers et al., 2001; Yasukawa et al., 2001). This rearrangement has also been described in $43 \%$ of blood samples from patients with non-proliferative malignancies (Rauzy et al., 1998). Similarly, the translocation $\mathrm{t}(9 ; 22)$ $B C R / A B L$ was primarily detected in peripheral lymphocytes of adults and children (Biernaux et al., 1995); Bose et al. (1998) subsequently confirmed these data by demonstrating p190 and p210 transcripts in 4 of 11 and 11 of 16 individuals, respectively. Other markers have also been detected at low frequencies in normal populations, including ETV6/RUNX1 (Eguchi-Ishimae et al., 2001; Brassesco et al., 2004), $\mathrm{t}(11 ; 14)(\mathrm{p} 13 ; \mathrm{q} 11) \quad L M O 2 / T C R$ and $\mathrm{t}(7 ; 14)(\mathrm{q} 34 ; \mathrm{q} 11)$ TCR/TAL2 (Marculescu et al., 2002) and $\mathrm{t}(15 ; 17) P M L / R A R A$, the latter characteristic of promyelocytic leukemia (Quina et al., 2000). The incidence of $M L L$ duplications in healthy donors is much higher, and are detectable in almost all samples by using sensitive PCR methods (Bäsecke et al., 2006). Together, these studies indicate that leukemia and lymphoma-associated translocations can be generated in normal hematopoietic cells without apparent oncogenic consequences.

Based on these findings, we used an inverse-PCR strategy to investigate the presence of $M L L$ translocations in peripheral blood lymphocytes from healthy individuals. Our results demonstrate the presence of $M L L$ fusions in these cells, thus indicating that these rearrangements are not restricted to malignant cells but may also be present in a subset of normal hematopoietic cells.

\section{Material and Methods}

\section{Probands}

Blood samples from 100 normal subjects (50 males, 50 females) were analyzed in this study. All of the subjects were healthy non-smokers 18 to 46 years old (mean $\pm \mathrm{SD}=$ $22.9 \pm 5.4$ years) with no previous history of drug treatment or chronic use of medicines. A single sample of $10 \mathrm{~mL}$ of peripheral blood was obtained from each individual after informed consent, and the samples were immediately coded to ensure the anonymity of the donors. The study was approved by the local ethics committee of the Clinical Hospital of the Faculty of Medicine (University of São Paulo, Ribeirão Preto, SP).

\section{Translocation analysis by inverse-PCR}

Inverse PCR was done according to Betti et al. (2001) with few modifications. Three micrograms of DNA was digested with a combination of Sau3AI and XbaI (10 units each) at $37^{\circ} \mathrm{C}$ overnight. The addition of $X b a \mathrm{I}$ prevented amplification of the native $M L L$ gene while allowing the amplification of translocation products that lacked the $X b a \mathrm{I}$ recognition site. After digestion, the samples were heatinactivated at $65{ }^{\circ} \mathrm{C}$ for $10 \mathrm{~min}$ and then purified with a Wizard SV Gel and PCR Clean-up System Kit (Promega
Corporation, Madison, WI, USA) to remove residual enzymatic activity. Following re-suspension in nuclease-free water, $0.5 \mu \mathrm{g}$ of digested DNA was self-ligated in the presence of 3 units of T4 DNA ligase in a final volume of $20 \mu \mathrm{L}$ for $16 \mathrm{~h}$ at $16^{\circ} \mathrm{C}$. All of the ligation reactions were terminated by incubation at $65^{\circ} \mathrm{C}$ for $10 \mathrm{~min}$. Eight microliters of ligated DNA was used in each PCR reaction. Nested primers were used to analyze the cleavage site at exon 12 of $M L L$ in two 28 -cycle reactions at temperatures of $95^{\circ} \mathrm{C}$, $55^{\circ} \mathrm{C}$ and $72{ }^{\circ} \mathrm{C}$ for $1 \mathrm{~min} / \mathrm{step}$.

The following primers were used: foward-1 5'-CTT TGTTTATACCACTC-3'; reverse-1 5'-TAGGGAATAT AAAAGAGTGGG-3'; forward-2 5'-TTAGGTCACTTA GCATGTTCTG-3' and reverse-2 5'-CAGTTGTAAGGT CTGGTTTGTC-3'. Strict precautions were taken in each step to avoid cross-contamination of the samples.

\section{Analysis of translocation DNA sequences}

PCR amplicons were separated on 1\% agarose gels. Individual I-PCR products were extracted from the gels with a GFX PCR DNA and Gel Band Purification kit (Amersham Biosciences, Buckinhamgshire, UK). The fragments were then cloned into the pGEM-T cloning vector (Promega Corporation, Madison, WI, USA), transformed into pMOS Blue Escherichia coli and selected on LB-agar plates containing ampicillin $(50 \mu \mathrm{g} / \mathrm{mL})$, according to the manufacturer's instructions. Individual transformed colonies were then expanded for $22 \mathrm{~h}$ in liquid culture. Three hundred nanograms of plasmidial DNA was used as a template for the sequencing reaction with a Big Dye Terminator Cycle Sequence Ready Reaction kit (Amersham Biosciences) and the products were analyzed in an ABI Prism 377 DNA Sequencer (Applied Biosystems, Wellesley, MA, USA). Quality analysis and the removal of vector sequences were done with phredPhrap software (Ewing et al., 1998; Ewing and Green, 1998). The resulting DNA sequences were then used to search the National Center for Biotechnology Information database with the Basic Local Alignment Search Tool (BLAST).

\section{Detection of $A F 4 / M L L$ translocations by RT-PCR}

Leukocytes from 22 healthy individuals were separated on Hystopaque-1077 (Sigma, St. Louis, MO, USA) and total RNA was extracted with TRIzol reagent (Gibco, BRL, USA), according to the manufacturer's instructions. After confirming the RNA quality by electrophoresis on a $1 \%$ agarose gel, reverse transcription was done using a High-Capacity cDNA Archive kit (Applied Biosystems, Foster City, CA, USA). Qualitative RT-PCR for the detection of translocation $\mathrm{t}(4 ; 11)(\mathrm{q} 21 ; \mathrm{q} 23)$ was done according to the standardized protocol described in the BIOMED-1 Concerted Action Report (Van Dongen et al., 1999) using the primer sets: $M L L-A$-CCGCCTCAGCCACCTAC-, $A F 4-B$-TGTCACTGAGCTGAAGGTCG-, $M L L-C$-AG GACCGCCAAGAAAAGA-, AF4-D -CGTTCCTTGCT 
GAGAATTTG- and $M L L-E$-AAGCCCGTCGAGGAAA AG-.

\section{Lymphocyte culture}

Lymphocytes were cultured using a standard protocol in which $0.5 \mathrm{~mL}$ of peripheral blood was added to $10 \mathrm{~mL}$ of RMPI 1640 medium (Sigma) supplemented with 20\% fetal calf serum, 2\% phytohemagglutinin (PHA) and penicillin/streptomycin. The cells were incubated at $37^{\circ} \mathrm{C}$ for $72 \mathrm{~h}$ and treated with colchicine $(0.56 \%)$ for the final $90 \mathrm{~min}$. Cell harvesting and slide preparation were done using standard methods. Slides for FISH were stored at $-20{ }^{\circ} \mathrm{C}$ until used.

\section{Fluorescence in situ hybridization}

FISH was done using the commercially available probes LSI MLL Break Apart Rearrangement, according to the manufacturers protocol (Vysis, Downers Grove, IL). The probe labeled with SpectrumGreen covered a $350 \mathrm{~kb}$ portion centromeric to the $M L L$ gene breakpoint region whereas the SpectrumOrange-labeled probe covered a $190 \mathrm{~kb}$ portion telomeric to the BCR. The expected signal pattern for a normal cell nucleus was two green(yellow)orange signals. In cells with $M L L$ translocations, the green and orange signals were separated without the yellow intersection. The advantage of this strategy was that it allowed the detection of translocations regardless of the partner involved. At least 1000 nuclei were analyzed and images were captured with an Axiovision System (Zeiss, Germany).

\section{Results}

Inverse PCR was used to screen the peripheral blood lymphocytes of normal individuals for $M L L$ translocations. In this strategy, the translocation region was excised with restriction enzymes, circularized and amplified using various $M L L$ primers. This approach allowed the detection of any rearrangement involving the cleavage site at exon 12 , which contains putative topoisomerase II recognition sequences and is sensitive to DNAse I and some cytotoxic agents.

Forty-nine of the 100 DNA samples that were screened contained bands of variable sizes that corresponded to alterations spanning the $M L L$ breakpoint region (Figure 1). In gel electrophoresis, the putative translocations resulted in one, two or three amplification products of 300-700 bp (amplification of the germ-line $M L L$ was prevented by treatment with $X b a \mathrm{I}$ ), which suggested that some individuals may have more than one $M L L$ translocation. The individual bands were separated by electrophoresis in $1 \%$ agarose gels and cloned into the pGEM-T vector, transformed in E. coli pMOS Blue cells and sequenced. BLAST analysis of individual amplicons confirmed that these rearrangements were unique and specific for $M L L$ rearrangements. Of the 35 clones that were obtained, $66 \%$ contained the translocation $\mathrm{t}(4 ; 11)(\mathrm{q} 21 ; \mathrm{q} 23)$, which fuses $M L L$ and

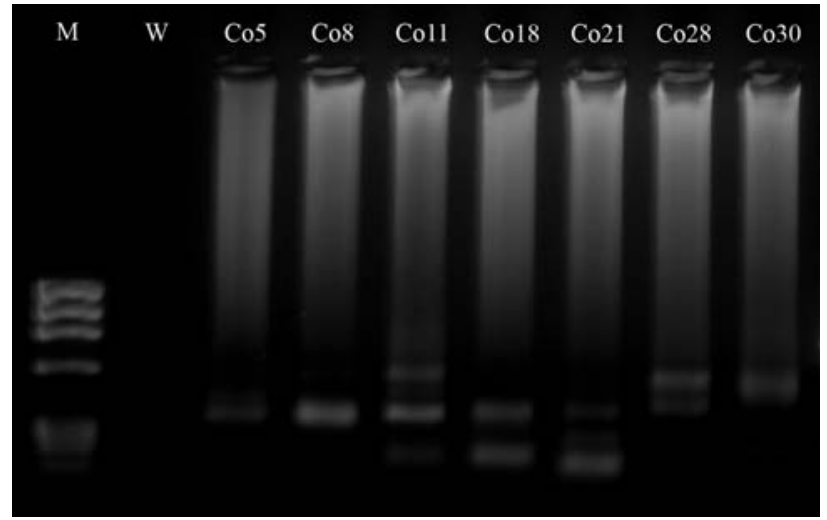

Figure 1 - Representative agarose gel showing PCR amplimers that probably resulted from translocation events at 11q23 $(M L L)$ in peripheral lymphocytes of healthy individuals. $\mathrm{M}=$ molecular weight marker $\Phi \mathrm{X} 174$; $\mathrm{W}=$ negative control; $\mathrm{Co}=$ control.

AF4 and occurs mainly in acute lymphoblastic leukemia. The remaining translocations fused $M L L$ to sequences located on chromosomes 1, 2, 9 ( 7 cases), 12 ( 2 cases) and 19 (Table 1). Although these chromosomes contain known MLL partner genes, such as EPS15 (1q32), MLLT11 (1q21), AF9 (9q34), CIP29 (12q13), ELL (19q13) and EEN (19q13) (Atlas of Genetics and Cytogenetics in Oncology and Haematology), the partner sequences did not match with specific chromosome bands. Interestingly, sequence analysis of the breakpoint junctions revealed short microhomologies (1-8 bp) suggestive of non-homologous end joining repair (NHEJ) (Figure 2).

Chromosomal preparations from 49 individuals were also analyzed using the LSI MLL (Vysis) commercial probe, which allows the detection of different rearrangements at $11 \mathrm{q} 23$. At least 1000 nuclei were analyzed per individual and the translocation frequencies were found to vary from zero to 0.3 events $/ 100$ cells (mean $\pm \mathrm{SD}=$ $0.04 \pm 0.06$ ). The specific probes also allowed the detection of extra signals, with frequencies ranging from zero to 0.79 signals $/ 100$ cells (mean $\pm \mathrm{SD}=0.18 \pm 0.19)$ (Table 2).

Together, these results raised the question of whether $M L L$ fusion genes were expressed at a transcriptional level. Since $\mathrm{t}(4 ; 11)$ was the most frequent translocation, RNA samples from 22 donors were screened for $M L L / A F 4$ transcripts using different primer sets that allowed the detection of all known fusion transcripts between exon 8 of $M L L$ and exon 7 of $A F 4$. No t $(4 ; 11)(\mathrm{q} 21 ; \mathrm{q} 23)$ transcripts were detected by RT-PCR in peripheral lymphocytes from healthy individuals (data not shown).

\section{Discussion}

The potential of the $M L L$ gene for recombination makes it difficult to detect aberrations by classic methods. Consequently, the detection of $M L L$ translocations is a challenge because although they have a known 5' sequence their 3 ' end can be one of a wide variety of translocation 
Table 1 - $M L L$ fusions detected by inverse PCR in peripheral blood lymphocytes from healthy individuals.

\begin{tabular}{|c|c|c|c|}
\hline Control & Clone & Translocation detected & e-value* \\
\hline Co 5 & 46 & $\mathrm{t}(4 ; 11)$ & $3 \mathrm{e}^{-99} ; 8 \mathrm{e}^{-50}$ \\
\hline $\operatorname{Co} 8$ & 47 & $\mathrm{t}(4 ; 11)(\mathrm{q} 21 ; \mathrm{q} 23)$ & $2 \mathrm{e}^{-14} ; 6 \mathrm{e}^{-42}$ \\
\hline \multirow[t]{2}{*}{ Co 11} & 48 & $\mathrm{t}(9 ; 11)$ & $9 \mathrm{e}^{-60} ; 2 \mathrm{e}^{-17}$ \\
\hline & 49 & $\mathrm{t}(9 ; 11)$ & $1 \mathrm{e}^{-74} ; 1 \mathrm{e}^{-15}$ \\
\hline Co 18 & 51 & $\mathrm{t}(4 ; 11)(\mathrm{q} 21 ; \mathrm{q} 23)$ & 0.008 \\
\hline Co 21 & 52 & $\mathrm{t}(2 ; 11)$ & $8 \mathrm{e}^{-04} ; 8 \mathrm{e}^{-04}$ \\
\hline Co 28 & 53 & $\mathrm{t}(9 ; 11)$ & $2 \mathrm{e}^{-172}$ \\
\hline Co 30 & 54 & $\mathrm{t}(4 ; 11)(\mathrm{q} 21 ; \mathrm{q} 23)$ & $3 \mathrm{e}^{-14} ; 8 \mathrm{e}^{-98}$ \\
\hline \multirow[t]{2}{*}{ Co 31} & 55 & $\mathrm{t}(4 ; 11)(\mathrm{q} 21 ; \mathrm{q} 23)$ & $3 \mathrm{e}^{-67} ; 4 \mathrm{e}^{-131}$ \\
\hline & $55-2$ & $\mathrm{t}(9 ; 11)$ & $0.003 ; 7 \mathrm{e}^{-146}$ \\
\hline Co 33 & 56 & $\mathrm{t}(4 ; 11)(\mathrm{q} 21 ; \mathrm{q} 23)$ & $3 e^{-58}$ \\
\hline Co 37 & 57 & $\mathrm{t}(4 ; 11)(\mathrm{q} 21 ; \mathrm{q} 23)$ & $6 \mathrm{e}^{-13} ; 1 \mathrm{e}^{-161}$ \\
\hline Co 39 & 59 & $\mathrm{t}(1 ; 11)$ & $5 \mathrm{e}^{-37} ; 1 \mathrm{e}^{-114}$ \\
\hline \multirow[t]{2}{*}{ Co 41} & 60 & $\mathrm{t}(11 ; 19)(\mathrm{q} 23 ; \mathrm{p} 13)$ & $6 \mathrm{e}^{-46} ; 9 \mathrm{e}^{-42}$ \\
\hline & $60-2$ & $\mathrm{t}(4 ; 11)(\mathrm{q} 21 ; \mathrm{q} 23)$ & $2 \mathrm{e}^{-21} ; 5 \mathrm{e}^{-41}$ \\
\hline Co 43 & 61 & $\mathrm{t}(4 ; 11)(\mathrm{q} 21 ; \mathrm{q} 23)$ & $6 \mathrm{e}^{-23} ; 4 \mathrm{e}^{-58}$ \\
\hline Co 44 & 62 & $\mathrm{t}(4 ; 11)(\mathrm{q} 21 ; \mathrm{q} 23)$ & 0.046 \\
\hline Co 49 & 63 & $\mathrm{t}(4 ; 11)(\mathrm{q} 21 ; \mathrm{q} 23)$ & $5 \mathrm{e}^{-38} ; 2 \mathrm{e}^{-145}$ \\
\hline Co 50 & 64 & $\mathrm{t}(4 ; 11)(\mathrm{q} 21 ; \mathrm{q} 23)$ & $3 e^{-57}$ \\
\hline Co 53 & 66 & $\mathrm{t}(4 ; 11)(\mathrm{q} 21 ; \mathrm{q} 23)$ & $1 \mathrm{e}^{-09}$ \\
\hline \multirow[t]{2}{*}{ Co 54} & 67 & $\mathrm{t}(4 ; 11)(\mathrm{q} 21 ; \mathrm{q} 23)$ & $1 \mathrm{e}^{-12} ; 2 \mathrm{e}^{-14}$ \\
\hline & 68 & $\mathrm{t}(4 ; 11)(\mathrm{q} 21 ; \mathrm{q} 23)$ & $2 \mathrm{e}^{-16} ; 7 \mathrm{e}^{-35}$ \\
\hline Co 58 & 70 & $\mathrm{t}(4 ; 11)(\mathrm{q} 21 ; \mathrm{q} 23)$ & $6 \mathrm{e}^{-15} ; 5 \mathrm{e}^{-77}$ \\
\hline \multirow[t]{2}{*}{ Co 61} & 72 & $\mathrm{t}(4 ; 11)(\mathrm{q} 21 ; \mathrm{q} 23)$ & $2 \mathrm{e}^{-58}$ \\
\hline & 73 & $\mathrm{t}(9 ; 11)$ & $2 \mathrm{e}^{-04}$ \\
\hline Co 63 & 74 & $\mathrm{t}(4 ; 11)(\mathrm{q} 21 ; \mathrm{q} 23)$ & $7 e^{-48}$ \\
\hline Co 70 & 75 & $\mathrm{t}(11 ; 12)$ & $5 \mathrm{e}^{-37} ; 2 \mathrm{e}^{-54}$ \\
\hline Co 71 & 115 & $\mathrm{t}(4 ; 11)(\mathrm{q} 21 ; \mathrm{q} 23)$ & $4 \mathrm{e}^{-52} ; 1 \mathrm{e}^{-24}$ \\
\hline Co 72 & 116 & $\mathrm{t}(4 ; 11)(\mathrm{q} 21 ; \mathrm{q} 23)$ & $8 \mathrm{e}^{-18}$ \\
\hline Co 84 & 117 & $\mathrm{t}(4 ; 11)(\mathrm{q} 21 ; \mathrm{q} 23)$ & $5 e^{-63}$ \\
\hline Co 97 & 118 & $\mathrm{t}(9 ; 11)$ & $1 \mathrm{e}^{-137} ; 8 \mathrm{e}^{-31}$ \\
\hline Co 98 & 119 & $\mathrm{t}(4 ; 11)(\mathrm{q} 21 ; \mathrm{q} 23)$ & 0.057 \\
\hline Co 99 & 120 & $\mathrm{t}(11 ; 12)$ & $3 \mathrm{e}^{-08} ; 7 \mathrm{e}^{-99}$ \\
\hline Co 113 & 121 & $\mathrm{t}(9 ; 11)$ & $2 \mathrm{e}^{-13}$ \\
\hline Co 114 & 122 & $\mathrm{t}(4 ; 11)(\mathrm{q} 21 ; \mathrm{q} 23)$ & $2 \mathrm{e}^{-57} ; 2 \mathrm{e}^{-36}$ \\
\hline
\end{tabular}

(*) value obtained by BLASTn analysis.

partners. The use of inverse PCR eliminates this problem by amplifying circularized fragments derived from any segment flanking a known DNA sequence. As shown here, $M L L$ fusion genes were detected in the peripheral lymphocytes of 49 of the 100 normal individuals examined in this work. The presence of these rearrangements was confirmed by FISH on interphase nuclei, and showed that $28.5 \%$ of the samples showed signal separation (based on the use of a specific dual-color "split-signal" DNA probe). The discrepancy between the results obtained with these two meth-
Table 2 - Frequencies of $M L L$ rearrangements and extra signals in peripheral blood lymphocytes from healthy individuals analyzed by FISH.

\begin{tabular}{lccccc}
\hline Controls & $\begin{array}{c}\text { Rearrange- } \\
\text { ments per } \\
100 \text { cells }\end{array}$ & $\begin{array}{c}\text { Extra } \\
\text { signals per } \\
100 \text { cells }\end{array}$ & Controls & $\begin{array}{c}\text { Rearrange- } \\
\text { ments per } \\
100 \text { cells }\end{array}$ & $\begin{array}{c}\text { Extra } \\
\text { signals per } \\
100 \text { cells }\end{array}$ \\
\hline Co-1 & 0.00 & 0.30 & Co-33 & 0.00 & 0.20 \\
Co-2 & 0.10 & 0.20 & Co-34 & 0.10 & 0.30 \\
Co-3 & 0.10 & 0.30 & Co-35 & 0.10 & 0.30 \\
Co-4 & 0.00 & 0.20 & Co-36 & 0.00 & 0.00 \\
Co-5 & 0.10 & 0.30 & Co-37 & 0.10 & 0.00 \\
Co-9 & 0.09 & 0.59 & Co-38 & 0.00 & 0.20 \\
Co-10 & 0.00 & 0.79 & Co-39 & 0.20 & 0.10 \\
Co-11 & 0.00 & 0.09 & Co-40 & 0.10 & 0.10 \\
Co-12 & 0.00 & 0.09 & Co-41 & 0.00 & 0.00 \\
Co-13 & 0.00 & 0.49 & Co-42 & 0.10 & 0.20 \\
Co-14 & 0.00 & 0.00 & Co-43 & 0.00 & 0.00 \\
Co-15 & 0.00 & 0.00 & Co-44 & 0.00 & 0.10 \\
Co-16 & 0.00 & 0.49 & Co-45 & 0.00 & 0.00 \\
Co-17 & 0.00 & 0.09 & Co-46 & 0.00 & 0.40 \\
Co-18 & 0.30 & 0.30 & Co-48 & 0.00 & 0.00 \\
Co-20 & 0.00 & 0.39 & Co-50 & 0.00 & 0.00 \\
Co-21 & 0.00 & 0.00 & Co-51 & 0.00 & 0.00 \\
Co-22 & 0.00 & 0.00 & Co-52 & 0.00 & 0.00 \\
Co-24 & 0.00 & 0.00 & Co-55 & 0.00 & 0.02 \\
Co-26 & 0.00 & 0.09 & Co-57 & 0.00 & 0.10 \\
Co-27 & 0.00 & 0.00 & Co-59 & 0.00 & 0.20 \\
Co-28 & 0.09 & 0.19 & Co-63 & 0.10 & 0.00 \\
Co-30 & 0.20 & 0.60 & Co-64 & 0.00 & 0.20 \\
Co-31 & 0.00 & 0.20 & Co-65 & 0.00 & 0.00 \\
Co-32 & 0.00 & 0.60 & & & \\
\hline & & & & & \\
\hline
\end{tabular}

ods probably reflects the difference in their sensitivities: whereas FISH can detect one positive cell in a thousand, PCR-based techniques can detect one cell in a million. Interestingly, 21 individuals who were negative for rearrangements by FISH had extra signals for the $M L L$ gene by PCR; these extra signals probably represented translocations with other gene partners.

Direct DNA sequencing of the inverse PCR amplicons showed that most of the fusion sequences were $\mathrm{t}(4 ; 11)(\mathrm{q} 21 ; \mathrm{q} 23)$; however, no $A F 4 / M L L$ transcripts were detected by RT-PCR (standardized for the study of minimal residual disease) in 22 RNA samples.

The results of this study show that $M L L$ rearrangements are not restricted to malignant cells but may also occur in normal hematopoietic cells. As indicated above, several studies have reported the presence of leukemialymphoma-associated fusion genes (e.g., $B C R / A B L 1$, $I G H / B C L 2, T C R \beta / \gamma)$ in normal individuals. In tandem partial duplications of $M L L$ have been detected in almost all bone marrow and peripheral blood samples from healthy 


\begin{tabular}{|c|c|c|c|}
\hline Subject & & Break junction & $M L L$ break site \\
\hline \multirow{3}{*}{ Co-5 } & Chr 4 & 3'AGTCTCCTGAGTAGCTGGGATCACAGGCGCGTGCACCACACCTGGCTA-5' & \multirow{3}{*}{54110} \\
\hline & & AGTCTCCTGAGTAGCTGGGATCACAACAGACTTGGCAATACACAAACT & \\
\hline & Chr 11 & 3'AACAAAACTTGTGGAAGGGCTCACAACAGACTTGGCAATACACAAACT-5' & \\
\hline \multirow{3}{*}{ Co-11 } & Chr 4 & 5'-CCAGGTGTGGTGCACGCGCCTGTGATCCCAGCTACTCAGGAGACTGAG-3' & \multirow[t]{3}{*}{53410} \\
\hline & & TTGTGTATTGCCAAGTCTGTTGTGATCCCAGCTACTCAGGAGACTGAG & \\
\hline & Chr 11 & 5'-ITGTGTATTGCCAAGTCTGTTGTGAGCCCTTCCACAAGTTTTGTTIAG-3' & \\
\hline \multirow{3}{*}{$\mathrm{Co}-12$} & Chr 4 & 5'-GCGGAGGTTGCAGTGAGTCGAGATCGCACCACTGCACCCCAGCCTG-3' & \multirow{3}{*}{53909} \\
\hline & & TATTACCACTTTAGTACTCTGAATCGCACCACTGCACCCCAGCCTG & \\
\hline & Chr 11 & 5'-TATTACCACTTTAGTACTCTGAATCTCCCGCAATGTCCAATACTGT-3' & \\
\hline \multirow{3}{*}{$\mathrm{Co}-27$} & Chr 4 & 3'-TTGGTGATCATGGGCCAGATCTGAGTTCAAATTTAGTGC-5' & \multirow[t]{3}{*}{53530} \\
\hline & & GTCTCCTGAGTAGCTGGGATCTGAGTTCAAATTTAGTGC & \\
\hline & Chr 11 & 3'- GTCTCCTGAGTAGCTGGGATCACAGGCGCGTGCCACCAC-5' & \\
\hline
\end{tabular}

Figure 2 - Illustrative $M L L$ translocations detected by inverse PCR in four subjects. Individual breakpoints are flanked by the germ-line $M L L$ sequence and sequences at chromosome 4. "Break site" refers to the position relative to the $M L L$ gene (GenebankTM accession number Y373585) fused to its partner. Grey boxes indicate short microhomologies between $M L L$ and $A F 4(4 \mathrm{q} 21)$.

donors (Schnittger et al., 1998; Bäsecke et al., 2002, 2006), but there is only one report of translocations involving $M L L$ in normal individuals. Uckum et al. (1998) used nested PCR to show that rearrangements involving $M L L$ and the transcription factor $A F 4$, resulted in the translocation $\mathrm{t}(4 ; 11)(\mathrm{q} 21 ; \mathrm{q} 23)$ in bone marrow samples from fetuses and normal children, as well as in fetal liver samples.

These findings indicate that such translocations per se do not define clinically apparent diseases, but rather that malignant progression appears to depend on additional factors such as the occurrence of oncogenic secondary alterations. Leukemia-associated gene fusions are generally believed to occur in utero, before birth. For twins with concordant leukemia and $M L L$ aberrations, the concordance rate reaches almost $100 \%$ (Greaves, 2002) and retrospective studies have shown the clonality of the rearrangements (Gale et al., 1997). According to Greaves and Wiemels (2003), the Knudson model, in addition to the twin concordance data, indicates that for every child with a particular translocation-positive leukemia, there has to be a greater number of healthy individuals that harbor the same translocation in a silent pre-leukemic clone. Similar studies of umbilical cord blood samples have shown that the frequencies of ETV6/RUNX1 and RUNX1/ETO, for example, are 100 times higher in neonates than in pediatric leukemia patients (Mori et al., 2002). These rearrangements may occur in a high proportion of developing fetuses, but without the production of functional chimeric proteins; alternatively, they could originate through inappropriate cellular conditions (Kim-Rouille et al., 1999).

Specific breaks involving the $M L L$ gene can be induced by a variety of stimuli associated with cellular stress or apoptosis, such as serum starvation or treatment with cytosine arabinoside (Stanulla et al., 1997; Betti et al., 2001; Vaughan et al., 2005). The activation of some components of the apoptotic process under these conditions has been demonstrated (Alam et al., 1999), and cells can recover the normal phenotype in the absence of phagocytic signals (Reddien et al., 2001). Based on these considerations, it seems plausible that $M L L$ rearrangements in normal individuals could result from exposure to genotoxic agents. The involvement of epipodophylotoxins in anomalies of this gene in therapy-related leukemias, and the evidence that neonatal leukemia originates in utero, have led to the hypothesis that maternal exposure to topoisomerase II inhibitors during pregnancy could be associated with an increased risk of leukemia (Ross, 2000). Synthetic and natural flavonoids bind to topoisomerase II to form a cleavable complex, despite the paradoxical finding that in some cases these compounds are anticarcinogenic (Greaves, 1997). Strick et al. (2000) demonstrated that natural flavonols such as quercetin and fisetin induced the same level of breaks at $11 \mathrm{q} 23$ as did etoposide, whereas luteolin and genistein were two-fold less effective than this drug and, in some cases, their combination had a cumulative effect in inducing $M L L$ cleavage.

Epidemiological studies have shown a significant association between infant leukemias and maternal exposure to various chemicals (Shu et al., 1996, 1999; Schuz et al., 2000; Ma et al., 2002; Mucci et al., 2004). In the specific case of infant leukemia with $M L L$ gene fusions, a casecontrol study identified significant variations in the ingestion of herbal medicines, drugs (e.g., Dipyrone), and insecticides (Alexander et al., 2001). A similar study that 
focused on maternal diet concluded that the ingestion of fruits and vegetables during pregnancy usually diminished the general risk of leukemia, although in the case of AML $M L L(+)$ exposure to certain natural topoisomerase II inhibitors appeared to increase the risk of disease (Spector et al., 2005).

According to Wiemels et al. (1999), the exposure of mothers and fetuses to dietary, medicinal and environmental substances that interact with topoisomerase II can be orders of magnitude lower in terms of dose level than for drugs used in chemotherapy. However, in some cases, these compounds are as biologically active as the topoisomerase II inhibitors used to treat cancer. The most abundant natural sources of topoisomerase inhibitors in a normal diet are fruits, vegetables and grains, which are rich in isoflavonoids. The antioxidant effect of these substances has been widely demonstrated (Prior, 2003), although epidemiological studies have shown that a high ingestion of isoflavonoids does not mean a reduced risk for all types of cancer (Hertog et al., 1994). In Asian countries, for example, the ingestion of isoflavonoids can reach $28 \mathrm{mg}$ /day (Fukutake et al., 1996; Nakamura et al., 2000). The plasma concentration of these substances after ingestion is relatively high (Franke et al., 1998; Watanabe et al., 1998) and can persist for two days. This finding suggests that the repeated inclusion of certain foods in the diet may ensure elevated plasma levels of these compounds (Hollman et al., 1997; de Vries et al., 1998).

Wiemels et al. (1999) also suggested that interindividual variation in drug metabolism by phase I and phase II detoxifying enzymes could play an important role in modulating the response to low doses of topoisomerase II inhibitors. Thus, for example, the frequency of $N Q 01$ (NAD(P)H: quinone oxido-reductase) low-activity alleles is 2.5 times lower in patients with $A F 4 / M L L$ fusions than in the normal population. Similarly, polymorphisms in CYP3A4 (which converts epipodophylotoxins into catechol metabolites) have been associated with an increased risk of leukemia (Felix et al., 1999). Uncontrolled exposure to certain substances and their metabolites can also contribute to gene fusions. Thus, hybrid genes that are present at low frequencies in peripheral blood of normal individuals tend to be more common in exposed populations, as in the case of the $T C R \beta / \gamma$ hybrid gene in agricultural workers exposed to pesticides (Lipkowitz et al.,1992) and the translocation $\mathrm{t}(14 ; 18)$ in smokers (Bell et al., 1995).

Our study group consisted of healthy non-smokers with no previous history of drug treatment or chronic use of medicines. However, the presence of $M L L$ fusions in peripheral blood lymphocytes of these individuals may have been related to previous exposures to substances from a variety of sources. Since lymphocytes circulate continuously they are considered to be more vulnerable to chemical or physical agents than other cell types (Tucker and Preston, 1996).
Tumor-associated translocations in peripheral lymphocytes may be transitory since sequential blood samples were not always positive for gene fusions, as shown for the $B C R / A B L$ hybrid gene (Biernaux et al., 1995). Other authors have suggested that such rearrangements may be expressed in hematopoietic cells that have entered the apoptotic pathway and have already lost their relevance (Bose et al., 1998). On the other hand, whereas the genetic regulation mediated by $M L L$ is important during hematopoietic differentiation, the expression of this gene (or of the fusion products) may be irrelevant in mature cells.

This study is the first to report the presence of $M L L$ fusion genes at a genomic level in peripheral blood lymphocytes of healthy adults. To date, all screenings of leukemia-associated rearrangements have been based on RT-PCR. The AF4/MLL fusion transcripts were initially described in normal individuals (Uckum et al., 1998) but subsequent studies failed to detect any transcription of this rearrangement (Kim-Rouille et al., 1999; Trka et al., 1999). In agreement with the latter studies, our results show that blood cells do not express detectable levels of $A F 4 / M L L$ transcripts and there is no a fortiori synthesis of the chimeric protein. In addition, sequencing of the PCR products, which provides breakpoint information, showed that in most cases the translocations were not in frame, thus strengthening the hypothesis that they may be tolerated for years without adverse consequences.

The biological significance of fusion genes and their respective chimeras in differentiated cells is still uncertain, and an important question remains about their oncogenic potential in healthy individuals. Nevertheless, the high proportion of $M L L$ rearrangements in normal individuals suggests that $11 \mathrm{q} 23$ anomalies may possibly result from exposure to endogenous or exogenous DNA-damaging agents. In practical terms, the high susceptibility of the $M L L$ gene to chemically-induced damage suggests that monitoring the aberrations associated with this gene in peripheral lymphocytes may be a sensitive assay for assessing genomic instability in individuals exposed to genotoxic stress.

\section{Acknowledgments}

We thank all of the donors who generously cooperated in this study, and Sueli A. Neves, Luiz A. da Costa Jr. and Mendelson Mazucato for technical assistance. This work was supported by FAPESP (grant n. 02/13317-8 and 03/01915-0), CAPES and CNPq.

\section{References}

Adler HT, Chinery R, Wu DY, Kussick SJ, Payne JM, Fornace JR and Tkachuk DC (1999) Leukemic HRX fusion proteins inhibit GADD34-induced apoptosis and associate with the GADD34 and HSNF5/INI1 proteins. Mol Cell Biol 19:7050-7060. 
Alam A, Cohen LY, Aouad S and Sekaly RP (1999) Early activation of caspases during $T$ lymphocyte stimulation results in selective substrate cleavage in nonapoptotic cells. J Exp Med 12:1879-1890.

Alexander F, Patheal S, Biondi A, Brandalise S, Cabrera ME, Chan LC, Chen Z, Cimino G, Cordoba JC, Gu LJ et al. (2001) Transplacental chemical exposure and risk of infant leukemia with $M L L$ gene fusion. Cancer Res 61:2542-2546.

Bäsecke J, Griesinger F, Trümper L and Brittinger G (2002) Leukemia- and lymphoma-associated genetic alterations in healthy individuals. Ann Hematol 81:64-75.

Bäsecke J, Podleschny M, Clemens R, Schnittger S, Viereck V, Trümper L and Griesinger F (2006) Lifelong persistence of AML associated $M L L$ partial tandem duplications ( $M L L-$ PTD) in healthy adults. Leuk Res 30:1091-1096.

Bell DA, Liu Y and Cortopassi GA (1995) Occurrence of BCL-2 oncogene translocation with increased frequency in the peripheral blood of heavy smokers. J Natl Cancer Inst 87:223224.

Betti CJ, Villalobos MJ, Diaz MO and Vaughan TM (2001) Apoptotic triggers initiate translocations within the $M L L$ gene involving the nonhomologous end joining repair system. Cancer Res 61:4550-4555.

Biernaux C, Loos M, Sels A, Huez G and Stryckmans P (1995) Detection of major $B C R-A B L$ gene expression at a very low level in blood cells of some healthy individuals. Blood 86:3118-3122

Bose S, Deininger M, Gora-Tybor J, Goldman JM and Melo JV (1998) The presence of typical and atypical $B C R / A B L$ fusion enes in leukocytes from normal individuals: Biologic sig nificance and implications for the assessment of minimal residual disease. Blood 92:3362-3367.

Brassesco MS, Camparoto ML, Tone LG and Sakamoto-Hojo ET (2004) Analysis of ETV6/RUNX1 fusions for evaluating the late effects of cancer therapy in all (acute lymphoblastic leukemia) cured patients. Cytogenet Genome Res 104:346-351.

de Vries JHM, Hiollman PCH, Meyboom S, Buysman MNCP, Zosk Pl, Van Staveren WA and Katan MB (1998) Plasma concentrations and urinary excretion of the antioxidant flavonols quercetin and kaempferol as biomarkers for dietary intake. Am J Clin Nutr 68:60-65.

Echlin-Bell DR, Smith LL, Li L, Strissel PL, Strick R, Gupta V, Banerjee J, Larson R, Relling MV, Raimondi SC et al. (2003) Polymorphisms in the $M L L$ breakpoint cluster region (BCR). Hum Genet 113:80-91.

Eguchi-Ishimae M, Eguchi M, Ishii E, Miyasaki S, Ueda K, Kamada N and Mizutani S (2001) Breakage and fusion of the TEL(ETVO) gene in immature B lymphocytes. Blood 97:737-743.

Ewing B and Green P (1998) Base-calling of automated sequencer traces using Phred. II. Error probabilities. Genome Res 8:186-194.

Ewing B, Hillier L, Wendl MC and Green P (1998) Base-calling of automated sequencer traces using Phred I. Accuracy assessment. Genome Res. 8:175-185.

Felix CA, Walker AH, Lange BJ, Williams TM, Winick NJ, Cheung NKV, Lovett BD, Nowell PC, Blair IA and Rebbeck TR (1999) Association of CYP3A4 with treatment-related leukemia. Proc Natl Acad Sci USA 95:13176-13181.

Franke AA, Custer LJ and Tanaka Y (1998) Isoflavones in human breast milk and other biological fluids. Am J Clin Nutr $68: 1466 \mathrm{~s}-1473 \mathrm{~s}$
Fukutake M, Takahashi M, Ishida K, Kawamura H, Sugimura T and Wakayashi K (1996) Quantification of genistein and genistin in soybeans and soybean products. Food Chem Toxicol 34:457-461.

Gale KB, Ford AM, Repp R, Borkhardt A, Keller C, Eden OB and Greaves MF (1997) Backtracking leukemia to birth: Identification of clonotypic gene fusion sequences in neonatal blood spots. Proc Natl Acad Sci USA 94:13950-13954.

Greaves M (1997) Aetiology of acute leukaemia. Lancet 349:344-349.

Greaves M (2002) Childhood leukemia. Science, medicine, and the future. Br Med J 324:283-287.

Greaves M and Wiemels J (2003) Origins of chromosome translocations in childhood leukaemia. Nat Rev Cancer 3:1-7.

Hertog MG, Feskens EJ, Hollman PC, Katan MB and Kromhout D (1994) Dietary flavonoids and cancer risk in the Zutphen elderly study. Nutr Cancer 22:175-184.

Hollman PC, Van Tripj JM, De Vries MMJ and Katan MB (1997) Bioavailability of the dietary antioxidant flavonol quercetin in man. Cancer Lett 114:139-140.

Hunger SP and Cleary ML (1998) What significance should we attribute to the detection of MLL fusion transcripts? Blood 92:709-711.

Kim-Rouille MH, Macgregor A, Wiedermann LM, Greaves M and Navarrete C (1999) MLL/AF4 gene fusions in normal newborns. Blood 93:1107-1108.

Lipkowitz S, Garry VF and Kirsh IR (1992) Interlocus V-J recombination measures genomic instability in agriculture workers at risk for lymphoid malignancies. Proc Natl Acad Sci USA 89:5301-5305.

Liu Y, Hernandez AM, Shibata D and Cortopassi GA (1994) $B C L 2$ translocation frequency rises with age in humans. Proc Natl Acad Sci USA 91:8910-8914.

Ma X, Buffler PA, Gunier RB, Dahl G, Smith MT, Reinier K and Reynold P (2002) Critical windows of exposure to household pesticides and risk of childhood leukemia. Environ Health Perspect 110:955-960.

Marculescu R, Le T, Simon P, Jaeger U and Nadel U (2002) $\mathrm{V}(\mathrm{D}) \mathrm{J}$-mediated translocations in lymphoid neoplasms: A functional assessment of genomic instability by cryptic sites. J Exp Med 195:85-98.

Mori H, Colman SM, Xiao Z, Ford AM, Healy LE, Donaldson C, Howa JM, Navarrete C and Greaves M (2002) Chromosome translocations and covert leukemic clones are generated during normal fetal development. Proc Natl Acad Sci USA 99:8242-8247.

Mucci LA, Granath F and Cnattingius S (2004) Maternal smoking and childhood leukemia and lymphoma risk among 1.440.542 Swedish children. Cancer Epidemiol Biomarkers Prev 13:1528-1532.

Nakamura Y, Tsuji S and Tonogai Y (2000) Determination of the levels of isoflavonoids in soybean and soy-derived foods and estimation of the isoflavonoids in the Japanese daily intake. J Aoac Int 83:635-650.

Nilson I, Lochner K, Siegler G, Greil J, Beck JD, Fey GH and Marschalek R (1996) Exon/intron structure of the human $A L L-1$ (MLL) gene involved in translocations to chromosomal region 11q23 and acute leukaemias. Br J Haematol 93:966-972.

Popovic R and Zeleznik-Le NJ (2005) MLL How complex does it get? J Cell Biochem 95:234-242. 
Prior RL (2003) Fruits and vegetables in the prevention of cellular oxidative damage. Am J Clin Nutr 78:570s-578s.

Quina AS, Gameiro P, Sá da Costa M, Telhada M and Parreira L (2000) PML-RARA fusion transcripts in irradiated and normal hematopoietic cells. Genes Chrom Cancer 29:266-275.

Reddien PW, Cameron S and Horvitz HR (2001) Phagocyte promotes programmed cell death in $C$. elegans. Nature 412:198-202.

Ross JA (2000) Dietary flavonoids and the $M L L$ gene: A pathway to infant leukemia? Proc Natl Acad Sci USA 97:4411-4413.

Ruazy O, Galoin S, Chale JJ, Adoue D, Albarede G, Delsol G and Al Saati T (1998) Detection of $t(14 ; 18)$ carrying cells in bone marrow and peripheral blood from patients affected by non-lymphoid diseases. Mol Pathol 51:333-338.

Sai-Peng S and Liu LF (2001) Nucleolytic cleavage of the mixed leukemia breakpoint region during apoptosis. J Biol Chem 276:31590-315995.

Schnittger S, Wormann B, Hiddermann W and Griesinger F (1998) Partial tandem duplications of the MLL gene detectable in peripheral blood and bone marrow of nearly all healthy donors. Blood 92:1728-1734.

Schuz J, Kaletsch U, Meinert R, Kaatsch P and Michaelis J (2000) Risk of childhood leukemia and parental self-reported occupational exposure to chemicals, dusts, and fumes: Results from pooled analyses of German population-based casecontrol studies. Cancer Epidemiol Biomarkers Prev 9:835838.

Shu XO, Ross JA, Pendergrass TW, Reaman GH, Lampkin B and Robison LL (1996) Parental alcohol consumption, cigarrette smoking, and risk of infant leukemia: A children's cancer group study. J Natl Cancer Inst 3:24-31.

Shu XO, Stewart P, Wen WQ, Han D, Potter JD, Buckley JD, Heineman E and Robison L (1999) Parental occupation exposure to hydrocarbons and risk of acute lymphoblastic leukemia in offpring. Cancer Epidemiol Biomarkers Prev 8:783-791.

Slany RK (2005) When epigenetics kills: $M L L$ fusion proteins in leukemia. Hematol Oncol 23:1-9.

Spector LG, Xie Y, Robison LL, Heerema NA, Hilden JM, Lange B, Felix CA, Davies SM, Slavin J, Potter JD et al. (2005) Maternal diet and infant leukemia: The DNA topoisomerase II inhibitor hypothesis: A report from the children's oncology group. Cancer Epidemiol Biomarkers Prev 14:651-655.

Stanulla M, Wang J, Chervinsky DS, Thandla S and Aplan PD (1997) DNA cleavage within the $M L L$ break cluster region is a specific event which occurs as part of higher-order chromatin fragmentation during the initial stages of apoptosis. Mol Cell Biol 17:4070-4079.

Strick R, Strissel P, Borgers S, Smith SL and Rowley JD (2000) Dietary flavonoids induce cleavage in the $M L L$ gene and may contribute to infant leukemia. Proc Natl Acad Sci USA 97:4790-4795.

Strout MP, Marcucci G, Bloomfield CD and Caligiuri MA (1998) The partial tandem duplication of ALL1 (MLL) is consistently generated by $A l u$-mediated homologous recombination in acute myeloid leukemia. Proc Natl Acad Sci USA 95:2390-2395.

Summers KE, Goff LK, Wilson AG, Gupta RK, Lister TA and Fitzgibbon J (2001) Frequency of the BCL2/IGH rearrange- ment in normal individuals: Implications for the monitoring of disease in patients with follicular lymphoma. J Clin Oncol 19:420-424.

Trka J, Zuna J, Hrusak O, Michalova K, Muzikova K, Kalinova $\mathrm{M}$, Horak J and Stary J (1999) No evidence for MLL/AF4 expression in normal cord blood samples. Blood 93:11061107.

Tucker JD and Preston RJ (1996) Chromosome aberrations, micronuclei, aneuploidy, sister chromatid exchanges and cancer risk assessment. Mutat Res 365:147-159.

Uckum FM, Herman-Haten K, Crotty ML, Sensel MG, Sather HN, Tuel-Ahlgren L, Sarquis MB, Bostrom B, Nachman JB, Steinherz PG et al. (1998) Clinical significance of $M L L-A F 4$ fusion transcript expression in the absence of a cytogenetically detectable $\mathrm{t}(4 ; 11)(\mathrm{q} 21 ; \mathrm{q} 23)$ chromosomal translocation. Blood 92:810-821.

Van Dongen JIM, Macintyre EA, Delabesse E, Rossi V, Saglio G, Gottardi E, Rambaldi A, Dotti G, Griesinger F, Parreira A et al. (1999) Standardized RT-PCR analysis of fusion transcripts from chromosome aberrations in acute leukemia for detection of minimal residual disease. Leukemia 13:19011928.

Vaughan AT, Betti CJ, Villalobos MJ, Prenkumar K, Cline E, Jiang Q and Diaz MO (2005) Surviving apoptosis: A possible mechanism of benzene-induced leukemia. Chem Biol Interact 153-154:179-185.

Watanabe S, Yamaguchi M, Sobue T, Takahashi T, Miura T, Arai Y, Mazur W, Wahala K and Adlercrutz H (1998) Pharmacokinetics of the soybean isoflavones in plasma, urine and feces of men after ingestion of $60 \mathrm{~g}$ baked soybean powder (kinako). J Nutr 128:1710-1715.

Whitman SP, Strout MP, Marcucci G, Freud AG, Culley LL, Zeleznik-Le NJ, Mrozek K, Theil KS, Kees UR, Bloomfield $\mathrm{CD}$ et al. (2001) The partial nontandem duplication of the $M L L$ ( $A L L 1)$ gene is a novel rearrangement that generates three distinct fusion transcripts in B-cell acute lymphoblastic leukemia. Cancer Res 61:59-63.

Wiemels JL, Pagnamenta A, Taylor MG, Eden OB, Alexander FE, Greaves MF and United Kingdom Childhood Cancer Study Investigators (1999) A lack of a functional $N A D(P) H$ :quinone oxidoreductase allele is selectively associated with pediatric leukemias that have $M L L$ fusions. Cancer Res 59:4095-4099.

Yasukawa M, Banso S, Dolken G, Sada E, Yakushjin Y, Fujita S and Makino H (2001) Low frequency of BCL2/JH translocation in peripheral blood lymphocytes of healthy Japanese individuals. Blood 98:486-488.

\section{Internet Resources}

Atlas of Genetics and Cytogenetics in Oncology and Haematology, http://atlasgeneticsoncology.org/Genes/MLL.html, accessed September $\left.8^{\text {th }}, 2007\right)$.

Basic Local Alignment Search Tool (BLAST), http://www.ncbi.nlm.nih.gov/BLAST.

Associate Editor: Emmanuel Dias Neto

License information: This is an open-access article distributed under the terms of the Creative Commons Attribution License, which permits unrestricted use, distribution, and reproduction in any medium, provided the original work is properly cited. 